\title{
A UTILIDADE DE UMA INVESTIGAÇÃO EXATA: LITERATURA E EDUCAÇÃO
}

\author{
Leandro Thomaz de Almeida ${ }^{1}$
}

\begin{abstract}
RESUMO: O presente artigo procurou resgatar alguns elementos do debate crítico suscitado pela literatura naturalista e relacioná-los com discussóes recentes no Brasil sobre a inadequação de alguns livros para uso na educaçáo básica, baseando-se nos exemplos de Monteiro Lobato e Adolfo Caminha. Para isso, realizou-se um levantamento de algumas acusaçóes, tais como as de obscenidade e imoralidade lançadas a muitos romances escritos em finais do século XIX, os quais despertaram reaçáo e defesa por parte dos escritores, notadamente o francês Émile Zola, cujos romances e obra teórica foram bastante discutidos no Brasil. A partir disso, esperou-se mostrar que o texto literário exige uma leitura capaz de considerar as especificidades de sua composição, o que levaria a uma abordagem do texto polêmico na educação diferente de sua simples condenação.
\end{abstract}

Palavras-chave: Literatura naturalista. Educação. Romance.

\section{THE USEFULNESS OF AN EXACT INVESTIGATION: LITERATURE AND EDUCATION}

\begin{abstract}
This article sought to address some elements of the critical debate elicited by naturalist literature and to associate them with recent discussions in Brazil about the inadequacy of some books for use in primary education, based on the examples of Monteiro Lobato and Adolfo Caminha. Thus, a survey on some accusations, such as obscenity and immorality released against many novels written in the late $19^{\text {th }}$ century, was carried out. These novels aroused reaction and defense by the writers, notably the French Émile Zola, whose novels and theoretical work were extensively discussed in Brazil. Therefore, it was expected to show that the literary text requires a reading able to consider the specificities of its composition, which would result in an approach to the controversial text in education other than its simple condemnation.
\end{abstract}

Keywords: Naturalist literature. Education. Novel.

\footnotetext{
${ }^{1}$ Universidade Estadual de Campinas (Unicamp), Instituto de Estudos da Linguagem - Campinas (SP), Brasil. E-mail: leandroth@gmail.com

DOI: 10.1590/ES0101-73302017139215
} 


\title{
L'UTILITÉ D'UNE ENQUÊTE EXACTE: LA LITTÉRATURE ET L'ÉDUCATION
}

\begin{abstract}
RESUMÉ: Cet article vise à dégager quelques éléments du débat critique suscité par la littérature naturaliste et les relier à des discussions récentes au Brésil au sujet de l'insuffisance de certains livres pour une utilisation dans l'éducation de base, prenant les exemples de Monteiro Lobato et Adolfo Caminha. Pour cela, on effectue un relevé de quelques accusations telles que l'obscénité et l'immoralité lancées à des nombreux romans écrits à la fin du XIXe siècle, qui ont suscité la réaction et la défense par des écrivains, plus notamment le français Émile Zola, dont les romans et les œuvres théoriques ont été largement débattus au Brésil. Cela dit, il est prévu de montrer que le texte littéraire exige une lecture en mesure d'examiner les détails de sa composition, ce qui conduirait à une approche du texte controversé dans l'éducation différente de sa simple condamnation.
\end{abstract}

Mots-clés: Littérature naturaliste. Éducation. Roman.

\section{Introdução}

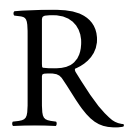

ecentemente, o trabalho de ficção desenvolvido por Monteiro Lobato despertou uma grande polêmica nos meios de comunicação brasileiros, opondo críticos e defensores da utilização de livros como Caçadas de Pedrinho na educação pública infantil. Os primeiros viam na história termos ofensivos aos afrodescendentes, sendo o próprio autor, Lobato, acusado de racista e fomentador de preconceito, razão pela qual seus livros deveriam ser substituídos ou incluir uma explicação em nota de rodapé que fosse capaz de anular seu suposto efeito prejudicial para as crianças. Os segundos, ou seja, os defensores da utilização de tais livros, por sua vez, se esforçaram em defender tanto a utilização do livro quanto tal autor, apresentando argumentos que variaram desde a acusação de "patrulha ideológica" por parte do "politicamente correto" na crítica à obra até a alegação de que Lobato não só não era racista como a própria literatura, em sentido geral, teria de ser excluída da escola caso o critério para seleção de livros fosse uma leitura dogmática dos parâmetros do Programa Nacional Biblioteca da Escola (PNBE), o qual pontua: "Não serão selecionadas obras que apresentem moralismos, preconceitos, estereótipos ou discriminação de qualquer ordem". A querela é sobejamente conhecida, motivo pelo qual não será abordada neste trabalho ${ }^{1}$.

A razão por que se aborda essa questão inicialmente no texto reside em seu valor para mostrar a atualidade de um debate sobre o papel da literatura no ensino formal brasileiro. Vale notar que, na discussão sobre a obra infantil de Monteiro Lobato, o lado que acusou o escritor de racismo admite explicitamente que a leitura de um livro contendo determinadas características pode causar algum tipo de dano ao 
meio social em que ele é apropriado, no caso, a escola: fomentar o racismo, despertar o preconceito e instigar a discriminaçáo. Náo apenas náo se negou a importância do papel da literatura, como este saiu reforçado do episódio, ainda que por via indireta. Além disso, a defesa da utilização dessas mesmas obras em nenhum momento contestou que a literatura produza efeitos, ou alegou que seja de tão somenos importância que o debate em questão é inútil. Ao contrário, um dos pontos mais ressaltados na defesa de Lobato foi justamente o caráter transgressor e não dogmático que marca a literatura, motivo pelo qual ela jamais deveria sofrer algum tipo de constrição que limitasse sua liberdade, inclusive para criar personagens estereotipados, enredos violentos ou diálogos ácidos capazes de açular preconceitos vigentes na sociedade.

Subjacente, portanto, ao debate está a admissão de que a literatura tem um papel importante a cumprir na educação formal, razão da necessidade de vigilância sobre ela ou de defesa de sua livre manifestaçâa. A fim de conferir a essas consideraçôes iniciais uma densidade proveniente do recuo histórico, evoca-se uma discussão em moldes semelhantes ocorrida no século XIX, voltada para a chamada literatura naturalista. A pretensão com isso não é comparar o episódio de Monteiro Lobato com o que ocorreu com o escritor francês Émile Zola, que será o ator principal destas linhas, mas mostrar o teor dos debates sobre uma literatura considerada prejudicial ao leitor e à sociedade, de modo a oferecer uma perspectiva que seja útil para se pensar:

1. que a censura à literatura, e mais especificamente ao romance, não é algo novo na discussão sobre os usos possíveis da ficção;

2. sobre a literatura naturalista como um momento de debates esclarecedores a respeito do amparo dos críticos na acusação da imoralidade proveniente desses romances de finais do século XIX;

3) a respeito da estratégia de defesa utilizada pelos autores naturalistas, os quais defendiam a ideia de que romances que expusessem o vício ofereciam um primeiro passo para sua cura;

4) sobre a utilidade de um debate desenrolado no passado para refletir sobre questóes contemporâneas envolvendo uma polêmica relacionada à literatura.

\section{Romance: um gênero sob suspeita}

Quando se aborda o romance moderno (novel, em inglês, em contraposição à romance), surgido na Inglaterra no século XVIII (WATT, 2010), as referências são os enredos que abordam o cotidiano e trazem para as histórias o tempo regulado pelo trabalho, cujos personagens evidenciam uma singularidade diferente dos estereótipos marcados e cujo desenrolar no enredo sofre transformação proveniente de mudanças psicológicas, familiares e sociais. São numerosos, embora não muito abonadores, os discursos que acompanharam o surgimento desses romances. 
Não raro submetidos à categoria de "livros frívolos", os romances foram, por exemplo, acusados de promover alteraçóes corporais de consequências nada desprezíveis. Os leitores que gastavam muito tempo em sua leitura poderiam sofrer com perda de apetite, taquicardia, atordoamento, irritabilidade, etc. (ABREU, 2003). Os malefícios de sua leitura atingiriam ainda ramos respeitáveis do saber, tais como a História, a Geografia, a Poesia e a Eloquência, uma vez que os romances, despreocupados com a exatidão dos acontecimentos históricos e inclinados a priorizar histórias de amor, prejudicariam o aprendizado advindo dessas fontes mais "confiáveis", ciosas da verdade, das temáticas nobres e do bom uso do idioma.

Periódicos como o London Magazine advertiam sobre a periculosidade do romance, maior ainda que a das más companhias, pois exercia um efeito permanente na memória dos leitores:

\begin{abstract}
Não se pode negar que os livros nos quais o amor é o único tema e as intrigas amorosas a única ocupação dos atores sejam mais perigosos até mesmo que as más companhias, já que a narração de cenas lascivas poderia chocar ouvidos ainda não endurecidos pelo vício, quando a representação ardente pintada num romance, e lida na privacidade do leitor, náo pode deixar de excitar desejos e deixar vestígios impuros na memória. (apud ABREU, 2003, p. 282)
\end{abstract}

Há que se notar que o romance surgiu como uma espécie de "primo pobre" na família dos gêneros ficcionais, conforme observou Antonio Candido (1987, p. 83), ao afirmar que "uma coisa, com efeito, era encontrar razóes justificativas para a epopéia ou a tragédia, a ode ou a sátira”, diferentemente dos romances, os quais "deviam parecer aos intelectuais o que hoje parecerá a fotonovela" (CANDIDO, 1987, p. 83).

Sem suporte na tradição clássica e não previsto nas retóricas e poéticas de maior prestígio, o gênero recebeu olhares enviesados por parte dos eruditos, preocupados com a qualidade daquilo que seria lido:

Ainda mais grave parecia o fato de a leitura de romances ser feita sem supervisão, não contando com a mediação de um padre ou de um ministro como ocorria com a leitura de textos religiosos, tampouco com a mediação de um professor ou de uma tradição de interpretação como se passava com os textos beletrísticos. (ABREU, 2003, p. 274)

Essa série de discursos e concepçóes sobre o romance foi responsável por uma associação fundamental, para a avaliação do gênero no século XIX, entre romance e moralidade. Às apropriaçóes negativas do romance tratou-se de contrapor argumentos que apontassem em direção contrária, ressaltando sua utilidade e familiaridade com gêneros consagrados. Foi o que fizeram aqueles que, à semelhança de Henry Fielding no prefácio a Joseph Andrews, trataram de associar o romance a algum gênero de 
prestígio, como a epopeia: "parece, acho eu, razoável tratá-lo como épico; ao menos, nenhum crítico pensou ser apropriado colocá-lo sob outra designação, ou encontrou um nome particular para esse gênero" (apud ABREU, 2003, p. 291). Ainda, tratou-se de mostrar que os romances estavam plenos de bons exemplos a serem seguidos, o que influenciaria de maneira positiva os leitores. A linguagem e o enredo acessíveis poderiam "prove[r] excelente uso e instrução, finalmente calculados para plantar as sementes da virtude na juventude" (apud ABREU, 2003, p. 291).

Dessa forma, para se justificar, o romance deveria, primordialmente, edificar e instruir e a diversão que ele pudesse causar deveria se subordinar a dois objetivos mais nobres e sérios, funcionando como uma forma mais fácil de atingi-los. Segundo Abreu (2003, p. 306),

embora o romance seja distinto da tradiçáo clássica na maior parte dos aspectos, é clara a semelhança, no que tange ao desejo de moralização, com o princípio horaciano da mistura entre deleite e utilidade (miscuit utile dulci).

O efeito disso é que "essa forma de justificar a leitura das belas-letras teve longa e ininterrupta vida” (ABREU, 2003, p. 306).

O cenário introdutório oferecido anteriormente é essencial para uma compreensão mais refinada do Naturalismo, movimento literário que floresceu na França nas últimas décadas do século XIX e se espalhou por todo o mundo, ganhando configuraçóes próprias, como aconteceu no Brasil.

\section{Naturalismo: literatura nascida em polêmica}

Segundo Baguley (1995), há que se falar em "naturalismos", e não somente em um único naturalismo, uma vez que essa literatura produzida inicialmente na França apresenta características variadas, as quais impossibilitam enquadrar um grande número de romances escritos no período em uma série de aspectos homogeneizantes. A ressalva é importante, pois o chamado Naturalismo foi um dos períodos da história literária que mais sofreram com o procedimento recorrente nos manuais de história da literatura, qual seja, enfeixar obras e autores a partir de características supostamente comuns e uniformes, gesto segundo o qual os romances seriam lidos com maior ou menor demonstração de fidelidade a tais características. No caso do Naturalismo, a doxa predominante pretende que os romances dele representativos evidenciem a famigerada influência do meio e da hereditariedade sobre os personagens, o que faria dos enredos variaçóes desse mesmo tema.

Segundo a perspectiva adotada neste trabalho, o empreendimento meramente classificatório não coopera para uma apreciação mais especializada do Naturalismo - nem da literatura como um todo. Portanto, apresentar-se-á o Naturalis- 
mo baseando-se na elaboração de seu maior teórico, Émile Zola, nome fundamental do movimento não só pelos seus romances, mas também pelo seu engajamento na defesa da literatura naturalista contra as variadas críticas por ela recebidas.

Uma das diretrizes mais marcantes do Naturalismo deveria ser sua pretensão de substituir a imaginação pela observação na criação literária. $\mathrm{O}$ próprio título de um dos mais importantes ensaios de Zola sobre o Naturalismo, $O$ romance experimental (1881), mostra sua proximidade com as diretrizes científicas de Claude Bernard, médico francês criador do método experimental.

A partir de $O$ romance experimental (1881), a ênfase recai sobre a exposição das coisas como elas são, mas não necessariamente como devem ser: "A ciência experimental não deve se preocupar com o porquê das coisas; ela explica o como e nada mais" (ZOLA, 1979, p. 27, grifo do autor). A resposta ao motivo certamente envolve consideraçóes que extrapolam os limites da simples observaçáo. Nas palavras de Claude Bernard que Émile Zola destaca em um trecho de suas correspondências, essa resposta se liga às aspiraçóes de nosso espírito, enquanto a experimentação interdita ultrapassar o limite do "como":

É necessário dizer ainda uma palavra sobre os limites que Claude Bernard traça à ciência. Para ele, nós ignoraremos sempre o porquê das coisas; nós só podemos saber o como. É isso que ele exprime nestes termos: 'A natureza de nosso espírito nos leva a procurar a essência ou o porquê das coisas. Nisto, nós visamos mais longe que o alvo que nos é dado alcançar; pois a experiência logo nos ensina que não devemos ir além do como, isto é, além da causa próxima ou das condições de existência dos fenômenos [...]' (ZOLA apud SUWALA, 1993, p. 114) ${ }^{2}$

No caso de Zola, as liçóes que ele obteve da filosofia experimental de Claude Bernard estão explícitas em seus escritos. Isso confere maior segurança para afirmar a sugestão exercida pelo cientista sobre o escritor e permite compreender de forma mais acurada o ideal artístico do autor. Similarmente ao cientista, o romancista também é um experimentador, pois ordena os personagens de modo a colocá-los em situaçóes que permitirão sua observação: "O problema consiste em saber o que determinada paixão, agindo num certo meio e em certas circunstâncias, produzirá sob o ponto de vista do indivíduo e da sociedade" (ZOLA, 1979, p. 99). Muito da crítica proposta por Zola se voltou contra o que ele chamou de idealistas, que são os "escritores que saem da observação e da experiência para basearem suas obras no sobrenatural e no irracional, que admitem em suma forças misteriosas, fora do determinismo dos fenômenos" (ZOLA, 1979, p. 49).

Todo esse panorama deve servir como apresentaçáo das diretrizes seguidas pela vertente mais importante do Naturalismo, que compareceria de maneira mais destacada junto à produçáo dos romancistas no Brasil. Essa petiçáo de princípio de Zola 
não deve levar a considerá-lo um ingênuo propugnador da objetividade total no trabalho romanesco, já que ela faz parte de uma estratégia de defesa do autor, bastante consciente dos limites advindos da incontornável subjetividade. Em suas correspondências, Zola mostrou ter conhecimento da influência exercida pelo fator humano na criaçáo:

Não temos mais a criação exata e real, mas a criação modificada pelo meio onde passa sua imagem. Nós vemos a criação em uma obra de arte através do homem, através de um temperamento, uma personalidade [...]. A realidade exata é então impossível em uma obra de arte. (ZOLA apud SUWALA, 1993, p. 67)

Ao comentar Germinie Lacerteux, dos irmãos Goncourt, Zola ressaltou a liberdade que deveria caracterizar o trabalho do escritor, defendendo que ele não hesite diante da "plena natureza humana", não esconda nada do "cadáver humano" e não deixe de se interessar nem mesmo pelas "nossas menores particularidades". Ele reconhece essa liberdade diante dos críticos avessos ao modo de tratamento da matéria próprio do Naturalismo, que vem marcado pelo temperamento particular de cada escritor: "por graça, deixai-o criar como bem lhe parece; ele não vos dará jamais a criação tal qual ela é; ele lha vos dará sempre vista através de seu temperamento" (ZOLA, 2002, p. 761).

Essas breves linhas sobre a concepçáo teórica do Naturalismo procuram destacar alguns elementos importantes para a discussão travada. Sob a bandeira naturalista, a elaboraçáo literária seria, supostamente, secundária ao objeto representado. A proeminência que tal literatura ao modo realista ${ }^{3}$ confere a esse objeto quer transmitir a aparência de neutralidade diante do que está sendo observado - daí a busca pela verossimilhança. Note-se, no entanto, que mesmo nesse caso não se pode olhar a literatura sem um distanciamento: o próprio Zola, maior interessado na "verdade" de seu empreendimento romanesco, admite a incontornável presença da subjetividade do escritor e de um posicionamento no conjunto das teorias miméticas que o antecederam. Sem atenção às discussóes subjacentes à constituição de um determinado ambiente de produção da literatura, a abordagem que se faz atualmente pode cair no simplismo de se acreditar que, entre o romance e a realidade, não há mais que uma relação de reflexo puro e simples ${ }^{4}$.

\section{Uma estratégia de defesa}

Pelas características da literatura naturalista e tendo ciência dos discursos que acompanharam o gênero romanesco desde seu surgimento, não é difícil adivinhar o efeito de romances como L'assommoir, Germinal ou Nana junto aos críticos. Não erra quem imagina daí decorrente uma pronta reprovação a livros que foram considerados fontes de má influência aos leitores. Um breve panorama da recepção crítica do Naturalismo será suficiente para apresentar o teor das acusações lançadas contra esses romances interessados em captar todas as esferas de vida em sociedade. 
Utiliza-se a síntese elaborada por Pagès (1989), que divide em três grandes blocos a crítica ao Naturalismo na França. O primeiro bloco encobre os anos de 1870 a 1877, sendo marcadamente de ordem moral e tendo como representante de destaque Jules Barbey d'Aurevilly. A predominância da moralidade significa uma rejeição sem concessóes do Naturalismo, cujo emblema maior é a série Les Rougon-Macquart de Zola.

D'Aurevilly entende que o autor de L'Assommoir contrapóe a "vida moral" à "física", resultando em uma aproximação muito perigosa entre as vidas humana e animal, como se Zola defendesse uma igualdade entre as espécies. $\mathrm{O}$ emprego de "matérias ignóbeis" e a exposição de "coisas vergonhosas" contribuem para a imoralidade da obra:

Eu não quero lembrá-lo daquilo que ele esquece, ou seja, que o emprego de matérias ignóbeis rebaixa a arte e a torna impossível. O Realismo mentiu! Há sempre em todo grande artista uma altura original e uma pureza de gênio, que rejeita tocar nessas coisas vergonhosas nas quais o autor de $l$ Assomoir não teme mergulhar sua mão. (D'AUREVILLY, 1902, p. 232-233)

A moralidade seria favorecida se o narrador estivesse disposto a julgar a cena narrada, conduzindo o leitor explicitamente às conclusōes mais nobres diante de situaçóes duvidosas ou que poriam em xeque a honra, sobretudo de personagens femininas. No entanto, o crítico lamenta em Zola justamente a ausência de juízo sobre o narrado:

Findo o diálogo, o romancista retomaria sua narrativa e sua página, aí lançando seu estilo e seu pensamento. Mas o senhor Zola náo tem nem estilo nem pensamento para lançar. Ele não tem no ventre mais do que a consciência dos seus personagens, que suas ignóbeis paixóes, suas horríveis maneiras de sentir e de se expressar. (D’AUREVILLY, 1902, p. 234)

O segundo período na cronologia de Pagès é dividido entre 1877 e 1885, e encontra em Ferdinand Brunetière seu crítico típico. Há uma preocupação maior em estabelecer balizas históricas para cotejar o Naturalismo com outros períodos literários, mas mesmo aí o saldo não é muito favorável aos romancistas. Brunetière associa naturalismo com materialismo, e o que resulta dessa associaçáo, portanto, não poderia contar muitos pontos para uma visão crítica que valorizaria o idealismo. Sobre a "arte materialista" de Zola e dos naturalistas, afirma Brunetière (2002, p. 3):

É uma arte que sacrifica a forma à matéria, o desenho à cor, o sentimento à sensação, o ideal ao real; que não recua nem diante da indecência nem diante da trivialidade, da própria brutalidade; que fala enfim sua linguagem à multidão, achando sem dúvida mais fácil dar a arte em pasto aos instintos mais grosseiros das massas que elevar sua inteligência até a altura da arte. 
Havia um interesse de que a arte desempenhasse algum papel educativo, apto a supostamente elevar a capacidade de exigência do contemplador da arte ou, no caso da literatura, de seu leitor. Para isso, essa arte teria de privilegiar a forma, o desenho, o sentimento e o ideal e suplantar a trivialidade e a brutalidade. O que a crítica propugna é um fazer artístico que se afasta dos motivos considerados indignos da arte presente em uma sociedade.

O terceiro período, finalmente, vai de 1885 a 1893, em que predomina, com Jules Lemaître, o critério estético, a partir do qual será recusada a pretensão científica do Naturalismo. Para Lemaître, o Naturalismo Zolaniano se aproxima da epopeia, "uma epopeia pessimista da animalidade humana" (Lemaître, s/d, p. 284), dada a sua pretensão de recobrir os vários aspectos da vida humana e dar destaque aos elementos considerados mais baixos e degradantes.

Diante de uma recepçáo predominantemente negativa de seus romances, Zola investiu em uma estratégia de defesa. É difícil precisar os limites claros entre o que ele, de fato, pensava em termos artísticos e o quanto suas declaraçóes eram, antes, meras estratégias defensivas que reclamavam tal ou qual posicionamento. De qualquer modo, o mais importante é perceber o teor da discussão envolvendo uma literatura tida como polêmica, pois é isso que será importante para se refletir sobre a relação entre a literatura e a educação ao final destas considerações.

A estratégia de Émile Zola utilizada em sua defesa foi apelar à ciência e ao papel educativo da arte. Assim, em nome da ciência, a valorização se dava ao gesto de observação impessoal da natureza; e o papel educativo adviria exatamente desse ato. Veja-se a seguir o passo a passo da construção do argumento.

Primeiramente, Zola rejeitou o que era considerado, para ele, uma constante na arte literária até então:

assim, numa personagem, deveremos fazer uma seleção: tomar os bons sentimentos, omitir os maus; e mesmo, seremos ainda mais recomendáveis, se inventarmos completamente a personagem, se a lançarmos no molde convencional do bom tom e da honra. (ZOLA, 1979, p. 105)

Essa declaração deve ser tomada em chave irônica, pois sua crítica se volta justamente aos arranjos depurativos capazes de enobrecer uma personagem. Contrariamente ao senso predominante, a moralidade de um romance estaria presente em sua decisão de não operar nenhum tipo de arranjo que viesse a amenizar o objeto presente no trabalho de representaçáo da realidade levado a cabo pelo romance:

em suma, a questão da moralidade no romance se reduz, portanto, a estas duas opinióes: os idealistas pretendem que é necessário mentir para ser moral; os naturalistas afirmam que não se poderia ser moral fora da verdade. (ZOLA, 1979, p. 106) 
Zola entende que há um papel a ser desempenhado pelos escritores:

\begin{abstract}
Ser mestre do bem e do mal, regular a vida, regular a sociedade, resolver com o tempo todos os problemas do socialismo, e, sobretudo, trazer bases sólidas para a justiça, resolvendo pela experiência as questóes de criminalidade, não é ser os operários mais úteis e mais morais do trabalho humano? (ZOLA, 1979, p. 49)
\end{abstract}

A interpretação dessas palavras de Zola pode ser reforçada pela proposta de Suwala, que enfatiza a ideia de que a elaboraçáo de uma imagem fiel do real por parte do autor é o caminho para a moralização da obra literária:

a este respeito, quanto mais a imagem que ele oferece da realidade é fiel, melhor ele preenche sua função investigadora. Por isso mesmo, ele pode também servir à moral: é a "moralização indireta pela exposição lógica e poderosa da verdade”. (SUWALA, 1993, p. 137)

É essa ligação entre moral e verdade que serve ao escritor naturalista para se livrar das acusaçóes de imoralidade. Sapiro (2011), dentro de uma perspectiva sociológica, resume de forma proveitosa a atitude dos autores naturalistas:

Contra esta concepção [de que a arte deveria alimentar no leitor o amor pelo belo e pelo bem], a corrente realista desenvolveu uma nova concepção das relaçóes entre estética e moral. Mostrar o mal não significa aprová-lo. É justamente o contrário. Não é por meio da idealização, mas da descriçáo da realidade tal qual ela é, é dizendo a verdade, que a literatura é útil. O princípio é emprestado do paradigma científico: o conhecimento do mal constitui uma etapa necessária para descobrir o remédio contra ele. Os realistas vão mesmo mais longe: no domínio moral, o conhecimento do mal e de suas consequências tem uma virtude pré-moral, o conhecimento do mal e de suas consequências tem uma virtude preventiva. (SAPIRO, 2011, p. 298)

Guiados por essa percepção, autores como Zola justificaram a presença de narradores pouco dispostos a emitirem opinióes sobre a matéria narrada. Esse é um aspecto importante a ser notado no Naturalismo, pois ele se constrói a partir de um elemento estritamente formal (o foco narrativo e a postura do narrador) que, para ser melhor compreendido, demanda um repertório advindo das circunstâncias concretas de produção do texto, no caso a preocupação com debates sobre moralidade no romance.

Diferentemente de muitos autores românticos, prontos a oferecerem ao leitor a interpretaçâo "correta" de determinada cena ou desenlace narrados, atitude justificada pela intenção moralizante da narrativa ${ }^{5}$, o autor naturalista elaborou um narrador impassível mesmo diante da cena mais repugnante. Isso não foi de- 
senvolvido não porque tenha abdicado da intenção moralizante, mas porque, em sua argumentação, esse gesto se constituía no modo mais fácil de atingi-la.

Mas como se daria essa moralização pelo exemplo, tấo invocada pelos autores naturalistas? Em seu artigo, "De la moralité dans la littérature", no qual procurou se defender das acusaçóes de obscenidade lançadas a sua obra, Zola ofereceu uma amostra prática da possível contribuição à sociedade fornecida pela literatura feita por ele. Ao retratar uma jovem dominada pela devassidáo, o romance naturalista investigou os motivos que a levaram a tal situação, com a possibilidades de que o "alcoolismo dos pais" ou as "promiscuidades dos subúrbios" em que ela vive tenham contribuído para isso:

Eis uma verdadeira meretriz, eis como ela se conduz e como ela trabalha em seguida, eis os fatos estabelecidos pela observação e experiência; doravante, porque a experiência nos torna mestres dos fatos, cabe a nós impedi-los de se produzir: saneemos os subúrbios, suprimamos cientificamente as meretrizes. E ainda que a obra não trouxesse essa conclusão prática, ela teria sempre a utilidade de uma investigaçáo exata, de uma verdade humana estabelecida, indestrutível. (ZOLA, 2002, p. 824)

De forma prática, portanto, o romance aponta a causa social do mau comportamento individual. As autoridades responsáveis deveriam intervir no ambiente que propiciaria a devassidão. Expor o cenário em sua mais ofensiva crueza é um ato de moralidade na medida em que contribui para a cura dos males sociais. Nesse aspecto, o próprio Zola acaba defendendo um "funcionamento ideal" do romance de difícil comprovação prática, como se a contemplação tanto do mal quanto de suas consequências no exercício de leitura conduzisse imediatamente o leitor ao desejo de saná-los ou desse a ele as ferramentas práticas para chegar a esse resultado.

No entanto, Zola parece acreditar nisso, embora defenda que haja maneiras específicas para se chegar a essa moralização.Podemos retomar o tema do narrador que se exime de julgar as açóes dos personagens, o que suscitou reprovaçôes de críticos também no Naturalismo. Inscrever tal debate sob a rubrica de mera escolha formal ou estilística dos escritores é uma opção que ignora uma discussão desenrolada sobre o modo de conduzir o leitor, que trava contato com a obra. Sapiro explicita o que está em jogo:

O leitor deve ser guiado por um narrador que julga as açóes dos personagens em termos das normas de moralidade, como pensava Balzac, ou que desaparece atrás deles, como queria Flaubert? $\mathrm{Na}$ esteira desse último, os romancistas naturalistas deixam, quanto a eles, 'a realidade se fazer liçáo a ela mesma'. 'O Naturalismo não se pronuncia. Ele examina. Ele descreve. Ele diz: Isto é. Cabe ao público tirar conclusóes', responde Zola a uma jornalista do Figaro de 18 de setembro de 1884 . À seduçáo, eles preferem 
a franqueza brutal. Eles creem inútil acompanhar seu estudo de um comentário moral. 'A vida contém nela seus ensinamentos', escreve Louis Desprez. Os leitores estão em condiçóes de chegar a uma conclusão. Seria injuriar sua inteligência crê-los incapazes de alcançá-la por si mesmos. (SAPIRO, 2011, p. 452)

Malgrado a diferença presente na manifestação da literatura entre a França e o Brasil, um aspecto é recorrente nos dois países: a acusação de imoralidade que acompanhou os romances de um e outro lado do Attântico. No caso brasileiro, o romance Bom-crioulo, e outros, como $A$ carne, de Júlio Ribeiro, ou $O$ homem, de Aluízio Azevedo, não escaparam às reprovações de críticos apoiados sobre alguma queixa contra o que seria a imoralidade difundida pelos seus enredos. Essa acusação comum fornece o elo para saltar de um cenário a outro. Desse modo, as consideraçôes adiante devem pressupor a densidade do debate proposto anteriormente.

\section{Cenário atual}

No Brasil, alguns romances naturalistas estão há muito tempo não só nas listas de leitura obrigatória para o vestibular, como também nos currículos escolares que indicam os livros a serem estudados nas aulas de literatura. Aqui se fará referência a um deles, o romance Bom-crioulo, de Adolfo Caminha (s.d.). Este se constitui em um bom exemplo para mostrar que a literatura, dado o seu caráter ficcional, merece um tratamento diferenciado das reprovaçóes apressadas e associaçóes pouco refletidas entre a opiniáo do autor e a do narrador do romance. Além disso, a obra traz, a seu modo, o panorama teórico explicitado anteriormente, pois se move na linha tênue entre a pretensão de fidelidade na descrição da sociedade e os limites que deve respeitar para não cair facilmente na acusação de imoralidade.

O enredo de Bom-crioulo tem como personagem principal o marinheiro Amaro, escravo fugitivo que encontra na Marinha um abrigo e uma possibilidade de uma nova vida. Ele sente uma forte atração por Aleixo, jovem grumete que embarca no mesmo navio do marinheiro. $\mathrm{O}$ romance mostrará as investidas de Amaro em direção a Aleixo; o caso amoroso que acaba por envolvê-los; e as dificuldades para sua manutenção, sobretudo depois que Aleixo se hospeda na casa de uma velha portuguesa e Amaro é obrigado a continuar suas viagens no navio. $\mathrm{O}$ tema do romance, portanto, não poderia ser mais polêmico: um caso de homossexualidade, entre um negro e um branco, na Marinha em finais do século XIX.

$\mathrm{O}$ que fazer diante de um romance que claramente não corresponde atualmente ao que seria o politicamente correto? $\mathrm{O}$ intercurso sexual entre dois homens é tido como um "delito contra a natureza" (CAMINHA, s.d., p. 30). Há descrições de Amaro que o associam à animalidade: "Dentro do negro rugiam desejos de touro ao pressentir a fêmea [...]" (CAMINHA, s.d., p. 39). A opinião 
de Aleixo não é nada favorável ao marinheiro: "ficara abominando o negro, odiando-o quase, cheio de repugnância, cheio de nojo por aquele animal com formas de homem, que se dizia seu amigo unicamente para o gozar" (CAMINHA, s.d., p. 56). O que o romance de Adolfo Caminha faz é veicular uma opinião corrente em seu tempo, porém não de maneira meramente irrefletida, como se o romance fosse um "reflexo" puro e simples da sociedade que lhe deu origem. Há de se levar em conta na leitura - e a aula de literatura será o lugar por excelência para fornecer aos alunos tal repertório - a inscrição estética do romance, no caso o Naturalismo, com todas as suas implicaçóes, as constriçóes provenientes do conservadorismo da sociedade, a expectativa que a obra causará entre críticos e a própria opinião corrente na sociedade sobre o tema nele abordado.

Levados em conta todos esses elementos, a leitura do romance ultrapassa a intenção meramente aprobatória ou condenatória de determinado tema ou o modo de abordá-lo. Uma leitura apressada de Bom-crioulo investiria, em um caso mais radical, em sua condenaçáo pelo modo como trata a homossexualidade. Mas o que se ganha com tal abordagem? Há, evidentemente, no romance uma espécie de condenaçâo da vivência homossexual de Amaro e Aleixo. No entanto, essa postura deve ser inscrita no conjunto de valores presentes na sociedade de origem do romance; a partir desse gesto, será possível perceber que, normalmente, a ficção oferece um olhar mais complexo para uma determinada realidade. Isso está presente em Bom-crioulo.

Vale notar também que, no âmbito da sociedade daquela época, a censura à homossexualidade era muito mais explícita do que aquela que aparece no romance. Como nos mostra Jurandir Freire da Costa, "é notável como, na abordagem do homossexualismo, os médicos limitavam-se a dizer que sentiam 'repugnância' pelos 'bagaxas' ou a compará-los à 'putrefação' que por vezes é preciso manejar para 'fertilizar a terra onde vai cair a boa semente'” (COSTA, 2004, p. 248). Em Bom-crioulo, não há a reproduçáo deste discurso, embora permaneça presente a intenção de verossimilhança, incontornável enquanto ideal da elaboração literária no âmbito do Naturalismo.

Uma vez que a concepção de Caminha, defendida em seus exercícios de crítica literária, era a de que a moral não deveria ser desprezada, porém comunicada "indiretamente e insensivelmente" pelo romance, sem "prédicas religiosas", é razoável compreender seu romance se movendo dentro desses limites. Em sua época, "criticava-se a própria atmosfera imoral da sociedade como sendo instigadora da prática homossexual" (COSTA, 2004, p. 248), a qual grassava preferencialmente entre "militares, artistas e empregados de comércio" (COSTA, 2004, p. 248) — segundo se supunha. Desse modo, tal obra poderia ser inscrita na explicação generalizada entre autores naturalistas para justificar a abordagem de temas considerados menos nobres: a cura se alcança pela exposição fiel da chaga. No caso de Bom-crioulo, a preocupação foi apenas apresentar alguns elementos teóricos e históricos presentes na época de seu lançamento. Ainda que não exaustivamente, eles são representativos de nuances 
que devem estar presentes na abordagem ao texto ficcional, sob pena de lançar juízos reprobatórios ou aclamatórios sobre este, unicamente por conta do tema abordado.

\title{
Conclusões
}

A escola deve ser o momento de proporcionar o enfrentamento da literatura, o qual assume vários sentidos: a lida com o texto propriamente dito, vencendo as dificuldades de interpretação ou mesmo a hermeticidade deles para conduzir o leitor a patamares mais elevados na decifração de signos e símbolos; o oferecimento de repertório capaz de amenizar a pouca familiaridade dos leitores contemporâneos com produções artísticas de outras épocas; e a abordagem de temas trazidos pela literatura associados à especificidade da expressão literária. Esse último aspecto é um dos mais importantes, e sobre ele valem algumas palavras a mais.

A exposição sobre a literatura naturalista apresentada procurou mostrar que, mesmo diante de temas considerados polêmicos, não se pode dissociar o assunto do modo como ele é veiculado. Sobre Monteiro Lobato, associou-se imediatamente o conteúdo dos seus livros de ficção com aquele de suas cartas pessoais, como se ambos tivessem o mesmo estatuto de verdade. No caso de Émile Zola ou Adolfo Caminha, é perceptível que a elaboração romanesca de cada um permite afirmaçóes que seriam impróprias em suas próprias manifestaçóes não ficcionais.

"Aprender" literatura é um processo de educação em um gênero textual com suas próprias especificidades. Não se trata apenas de opor a ficção à verdade, como se pode perceber na afirmação de Saer (2012, p. 2-3):

\begin{abstract}
A ficção, desde suas origens, soube emancipar-se dessas correntes. Mas que ninguém se confunda: não se escrevem ficçóes para eludir, por imaturidade ou irresponsabilidade, os rigores que o tratamento da "verdade" exige, mas sim para evidenciar o caráter complexo da situação, complexidade esta em que o tratamento limitado ao verificável implica uma redução abusiva e um empobrecimento. Ao ir em direção ao não verificável, a ficção multiplica ao infinito as possibilidades de tratamento. Náo nega uma suposta realidade objetiva, ao contrário, submerge-se em sua turbulência, desdenhando a atitude ingênua que consiste em pretender saber de antemão como essa realidade se conforma. Não é uma claudicação ante tal ou qual ética da verdade, mas sim a busca de uma ética um pouco menos rudimentar.
\end{abstract}

Reduzir a literatura e o aproveitamento do texto literário na educação a uma questão de adequação a essa ou àquela política educacional, sem a devida atenção à especificidade expressiva da ficção, é o mesmo que limitar seus possíveis alcances, mesmo educativos, a uma discussão dos temas por ela abordados, ou seja, como se a literatura meramente veiculasse conteúdo, 
independentemente da maneira pela qual o faz — uma maneira diferente dos demais gêneros textuais não ficcionais. $O$ que se procurou mostrar aqui é que a atenção aos elementos envolvidos na produção e leitura de romances pode se constituir em matéria de boa utilização da literatura na educação, mesmo quando seus temas são espinhosos. A condenação pura e simples da literatura tida como "politicamente incorreta", "obscena", "preconceituosa", etc. acaba por afastar os alunos do contato com pontos de vista com os quais eles podem deparar em seu próprio cotidiano. Tal literatura, ao trabalhar tanto a sua especificidade expressiva quanto o contexto de sua produção, oferece a possibilidade de enriquecimento do repertório pessoal, o que é um dos elementos decisivos na tarefa da formação educacional.

\section{Notas}

1. Para uma síntese das argumentaçôes em debate contra a adoção do livro, leia-se Feres Júnior, Nascimento e Eisenberg (2013). A favor de Lobato, dentre tantos artigos, pode-se consultar o abaixo-assinado encaminhado ao Ministério da Educação (MEC) contra o que seria uma censura à literatura, disponível em: <www.peticaopublica.com. br/?pi=P2012N29583>. Acesso em: 01 ago. 2014.

2. As traduçôes, salvo indicação contrária, foram feitas pelos autores do artigo.

3. Utiliza-se aqui "modo realista" para se referir à tradição literária que almeja alcançar uma representaçáo verossímil da esfera náo ficcional, o que engloba os mais variados períodos da história da literatura ocidental. Não confundir, portanto, com "gênero realista”, que é a designação específica de um período da literatura produzida no século XIX. A distinçáo pode ser conferida, com maiores nuances, em Baguley (1995).

4. Para aprofundamentos sobre a questão, ver Auerbach (2013), Lukács (2009) e Candido (2010).

5. "O narrador também não hesita em dar explicações aos leitores, antecipando-lhes as críticas e argumentando, a seu modo, em favor de seus pontos de vista. Sua atitude é a do mestre-escola paciente e interessado no aprendizado dos seus discípulos [...]” (LAJOLO, ZILBERMAN, 1991, p. 113).

\section{Referências}

ABREU, M.A. Os caminhos dos livros. Campinas: Mercado de Letras, Associação de Leitura do Brasil; São Paulo: Fapesp, 2003.

AUERBACH, E. Mimesis: a representaçâo da realidade na literatura ocidental. 6. ed. São Paulo: Perspectiva, 2013.

BAGULEY, D. Le naturalisme et ses genres. Paris: Nathan, 1995.

BRUNETIÈRE, F. Le roman naturaliste. Paris: Phénix, 2002.

CAMINHA, A. Bom-crioulo. São Paulo: Ediouro, s.d. 
CANDIDO, A. Literatura e sociedade: estudos de teoria e história literária. 11. ed. Rio de Janeiro: Ouro sobre Azul, 2010.

. Timidez do romance. In: A educação pela noite e outros ensaios. São Paulo: Ática, 1987.

COSTA, J. Ordem médica e norma familiar. 5. ed. Rio de Janeiro: Graal, 2004.

D'AUREVILLY, J. Barbey. Le Roman contemporain. Paris: Alphonse Lemerre Éditeur, 1902.

FERES JÚNIOR, J.; NASCIMENTO, L.F.; EISENBERG, Z.W. Monteiro Lobato e o politicamente correto. DADOS - Revista de Ciências Sociais, Rio de Janeiro, v. 56, n. 1, p. 69-108, 2013.

LAJOLO, M.; ZILBERMAN, R. A leitura rarefeita: livro e literatura no Brasil. São Paulo: Brasiliense, 1991.

LEMAÎTRE, Jules. Les contemporains - études et portraits littéraires. Première Série. Paris: Boivin \& Cie. Éditeurs, s/d.

LUKÁCS, G. A teoria do romance: um ensaio histórico-filosófico sobre as formas da grande épica. Tradução, posfácio e notas de José Marcos Mariani de Macedo. São Paulo: Livraria Duas Cidades; 34, 2009.

PAGÈS, A. La bataille littéraire. Paris: Librairie Séguier, 1989.

SAER, J.J. O conceito de ficção. FronteiraZ, São Paulo, n. 8, jul. 2012.

SAPIRO, G. La responsabilité de l'écrivain: litterature, droit et morale en France (XIX-XXI siècle). Paris: Éditions du Seuil, 2011.

SUWALA, H. Autour de Zola et du naturalisme. Paris: Honoré Champion, 1993.

WATT, I. A ascensão do romance: estudos sobre Defoe, Richardson e Fielding. Tradução de Hildegard Feist. São Paulo: Companhia das Letras, 2010.

ZOLA, E. O romance experimental e o naturalismo no teatro. Tradução de Ítalo Caroni e Célia Berrettini. São Paulo: Perspectiva, 1979.

. Oeuvres complètes. Tome 1: Les Débuts, 1858-1865. Publiées sous la direction de Henri Mitterand. Paris: Nouveau Monde, 2002.

Recebido em 13 de agosto de 2014.

Aprovado em 07 de novembro de 2016. 